\title{
Peranan Jamur Trichoderma sp yang Diberikan terhadap Pertumbuhan Tanaman Kedelai (Glycine max L.)
}

\author{
Syamsul Rizal, Titik Desi Susanti \\ *e-mail: syamsul_rizal_msi@yahoo.com \\ Program Studi Biologi, Fakultas MIPA, Universitas PGRI Palembang
}

\begin{abstract}
Research was conducted in the Science Center Laboratory of Universitas PGRI Palembang from November to February 2018. This research utilized the Completely Randomized Design with six level treatment and four replications. The objective of this research was recognized that the effect of Trichoderma sp was not significant to grow, baut had a very significant effect on plant height and number of leaves. The higher the dose give, the larger the diameter of the stem and the number of leaves.
\end{abstract}

Keywords : Trichoderma sp, plant growth, soybean crops

\begin{abstract}
ABSTRAK
Penelitian tentang pengaruh pemberian jamur Trichoderma sp yang diberikan terhadap pertumbuhan tanaman Kedelai (Glycine max L.), telah dilakukan di Laboratorium Terpadu Universitas PGRI Palembang dari bulan November 2017 sampai dengan bulan Februari 2018. Penelitian ini menggunakan Rancangan Acak Lengkap (RAL) dengan enam perlakuan dan empat ulangan. Hasil penelitian menunjukkan bahwa pemberian Trichoderma sp berpengaruh tidak nyata terhadap tinggi tanaman, namun berpengaruh sangat nyata terhadap diameter batang dan jumlah daun tanaman. Semakin tinggi dosis Trichoderma sp yang diberikan, semakin besar diameter batang dan jumlah daun.
\end{abstract}

Kata Kunci : Trichoderma sp, pertumbuhan tanaman, tanaman kedelai.

\section{PENDAHULUAN}

\section{Kedelai (Glycine $\max$ L.)} merupakan tanaman asli dari Cina dan telah menyebar ke beberapa negara seperti Jepang, Korea, India, Australia dan Amerika. Di Indonesia tanaman ini mulai dikenal oleh masyarakat khususnya pulau Jawa sekitar abad ke-16 yang dibawa oleh imigran Cina (Marianah, 2013).

Pemerintah Indonesia dari tahun ke tehun terus berupaya untuk meningkatkan produksi pertanian terutama produksi kedelai.Tanaman kedelai merupakan salah satu sumber protein nabati yang penting di Indonesia, namun peningkatan produksi kedelai ini masih belum dapat mengimbangi permintaan kedelai dalam negeri yang terus meningkat. Peningkatan bahan baku kedelai melonjak pesat dengan meningkatnya permintaan kedelai seiring perkembangan industri makanan, pakan ternak, susu, dan bahan kosmetik. Apalagi dengan bertambahnya jumlah penduduk yang membutuhkan kedelai sebagai protein nabati. Rendahnya produksi tanaman kedelai di Indonesia diantaranya disebabkan oleh kekeringan, benih yang kurang baik, persaingan gulma dan serangan penyakit (Kusumaningrum at al., 2007). 
Untuk meningkatkan pertumbuhan dan produksi kedelai, maka dapat dilakukan berbagai cara, salah satu diantaranya adalah penggunaan Trichoderma sp yang dapat membantu merangsang pertumbuhan tanamandan sebagai agen hayati.Trichoderma sp menginfeksi akar tanaman kedelai sehingga akar yang terinfeksi Trichoderma sp akan lebih banyak dibandingkan dengan akar yang tidak terinfeksi. Perakaran yang banyak tersebut menyebabkan penyerapan unsur hara lebih optimum, sehingga tanaman dapat tumbuh dengan baik. Trichoderma sp juga dapat menguraikan unsur hara yang terikat dalam tanah, menghasilkan antibiotik glikotoksin dan viridian yang dapat digunakan untuk melindungi bibit tanaman dari serangan penyakit serta mengeluarkan enzim $\beta$-1,3-glukanase dan kitinase yang dapat melarutkan dinding sel patogen (Ismail et al., 2011).

Hubungan timbal balik antara Trichoderma sp dengan tanaman adalah bersifat mutualisme. Tanaman diuntungkan dalam hal pertumbuhan maupun pengendalian penyakit, sedangkan Trichoderma sp diuntungkan karena dapat menyerap nutrisi yang dihasilkan oleh tanaman. Pemanfaatan Trichoderma sp diharapkan mampu meningkatkan produksi tanaman kedelai, khususnya dalam hal pertumbuhan tanaman dan pengendalian penyakit tanaman. Diharapkan dengan pemanfan Trichoderma sp dapat meningkatkan hasil yang optimal dan juga telah menerapkan sistem budidaya yang ramah lingkungan. Penambahan Trichoderma sp akan meningkatkan efisiensi pemupukan padatanaman yang dibudidayakan. Berdasarkan potensi yang dimiliki oleh Trichoderma sp diharapkan juga dapat mengurangi ketergantungan dan mengatasi dampak negatif dari pemakaian pestisida sintetik yang selama ini masih dipakai untuk mengendalikan penyakit pada tanaman (Zamriyetti dan Rambe, 2002).

Media pelet merupakan salah satu media yang dapat digunakan untuk memperbanyak Trichoderma sp. Pelet ni icocok digunakan untuk perbanyakan jamur. Pelet mengandung karbohidrat, protein dan kandungan nutrisi yang tinggi sehingga Trichoderma sp dapat berkembang biak dengan baik. Pelet adalah bentuk makanan buatan yang terdiri dari beberapa macam bahan yang di racik dan dijadikan adonan, kemudian dicetak berbentuk bulat kecilkecil.Biakan Trichodermasp dalam aplikasi seperti pelet dapat diberikan ke areal pertanaman dan berperan sebagai biodekomposer yang mendekomposisi limbah organik menjadi kompos yang bermutu, serta dapat berperan sebagai biofungisida yangmana jika Trichoderma sp ditambahkan kedalam tanah yang mengandung jamur patogen maka hifa Trichoderma spakan melilit dan tumbuh pada miselium inang.Beberapa jamur patogen penyebab penyakit pada tanaman dapat dikendalikan menggunakan Trichoderma sp, antara lain:Fusarium oxysforum, Phytium sp,Rhizoctonia solani dan Sclerotium rolfsii (Herlina, 2009).

Hasil penelitian Pasetriyani at al (2006), introduksi Trichoderma sp sebanyak 50 gram/polybagternyata dapat menekan penyakit Fusarium sp dan mempertahankan pertumbuhan (tinggi tanaman dan jumlah daun) serta hasil (jumlah dan bobot buah) tanaman tomat.Hasil penelitian Balai Pengkajian dan Pengembangan Teknologi Jawa Barat (2002), bahwa Trichoderma sp ternyata dapat memberikan pengaruh positif pada pertumbuhan vegetatif dan perkembangan generatif tanaman serta hasil panen. Tanaman yang diaplikasikan Trichoderma sp tumbuh dengan cepat dan subur, waktu pembungaan cepat dengan jumlah bunga dan jumlah polong yang lebih banyak dibandingkan dengan 
tanaman yang tidak diaplikasikan Trichoderma sp.Berdasarkan uraian diatas, penulis ingin mengetahui bagaimana pengaruh jamur Trichoderma sp terhadap pertumbuhan tanaman kedelai (Glycine max L.).

Berdasarkan hal tersebut penulis melaporkan hasil penelitian yang berjudul Peranan Jamur Trichoderma sp yang diberikan terhadap pertumbuhan tanaman kedelai (Glycine max L.).

\section{BAHAN DAN METODE}

Penelitian dilakanakan pada bulan Oktober 2017 sampai dengan bulan Februari 2018 di desa Ciptasari Kabupaten Ogan Komering Ilir Provinsi Sumatera Selatan.

Peralatan yang digunakan dalam penelitian ini adalah: penggaris,jangka sorong, timbangan, polibagukuran $3 \mathrm{~kg}$, kertas label, ember. Sedangkan bahan yang digunakan adalah: jamur Trichoderma sp dalam media pelet, tanah, benih kedelaidan air.

Penelitian ini menggunakan Rancangan Acak Lengkap (RAL) yang terdiri dari 6 perlakuan dan setiap perlakuan dilakukan sebanyak 4 kali ulangan.

\section{HASIL DAN PEMBAHASAN}

Hasil penelitian menunjukan bahwa pemberian Trichoderma sp terhadap pertumbuhan tinggi tanaman kedelai didapatkan rata-rata pertumbuhan tertinggi terdapat pada perlakuan $\mathrm{P}_{5}$ (dosis 125 gram Trichoderma $\mathrm{sp} / 2 \mathrm{~kg}$ tanah) dengan tinggi tanaman $41 \mathrm{~cm}$, sedangkan hasil terendah terdapat pada perlakuan $\mathrm{P}_{0}$ (kontrol/tanpa pemberian Trichoderma $\mathrm{sp}$ ) dengan tinggi tanaman $34,88 \mathrm{~cm}$

Hasil analisis sidik ragam menunjukan bahwa F-hitung lebih kecil dari F-tabel pada taraf 5\% dan 1\%. Hal ini menunjukkan bahwa pemberian jamur Trichoderma sp pada berbagai konsentrasi perlakuan berpengaruh tidak nyata terhadap tinggi tanaman kedelai .

Hasil analisis sidik ragam pengaruh pemberian jamur Trichoderma $\mathrm{sp}$ terhadap pertumbuhan diameter batang tanaman kedelai didapatkan hasil Fhitung lebih besar dari F-tabel pada taraf $5 \%$ dan $1 \%$. Hal ini menunjukkan bahwa pemberian Trichoderma sp pada berbagai konsentrasi perlakuan berpengaruh sangat nyata terhadap diameter batang tanaman kedelai maka dilakukan uji lanjut Beda Nyata Terkecil (BNT). Hasil uji BNT dapat dilihat pada Tabel 1 dibawah ini.

Tabel 1. Hasil Uji BNT Pengaruh Pemberian Jamur Trichoderma sp Terhadap Rata-rata Diameter BatangTanaman Kedelai pada Berbagai Konsentrasi Perlakuan.

\begin{tabular}{cc}
\hline Perlakuan & $\begin{array}{c}\text { Rata-rata Diameter Batang } \\
\text { TanamanKedelai }(\mathbf{c m})\end{array}$ \\
\hline $\mathrm{P}_{0}$ & $0,3 \mathrm{a}$ \\
$\mathrm{P}_{1}$ & $0,3 \mathrm{a}$ \\
$\mathrm{P}_{2}$ & $0,4 \mathrm{~b}$ \\
$\mathrm{P}_{3}$ & $0,4 \mathrm{~b}$ \\
$\mathrm{P}_{4}$ & $0,4 \mathrm{~b}$ \\
$\mathrm{P}_{5}$ & $0,5 \mathrm{c}$ \\
\hline BNT $^{(\mathbf{0 , 0 5})} \mathbf{0} \mathbf{0 , 0 6}$ &
\end{tabular}

Keterangan: Rata-rata dalam tabel yang diikuti oleh huruf yang sama artinya tidak berbeda $\begin{array}{llll}\text { nyata } & \text { pada uji } & \text { BNT }\end{array}$ 
Pada Tabel 2 dapat dilihat bahwa ratarata pemberianj amur Trichoderma $\mathrm{sp}$ terhadap pertumbuhan diameter batang tanaman kedelai yang tertinggi terdapat pada perlakuan $\mathrm{P}_{5}$ dengan diameter batang sebesar $0,5 \mathrm{~cm}$, sedangkan hasil terendah terdapat pada perlakuan $\mathrm{P}_{0}$ dan $\mathrm{P}_{1}$ dengan diameter batang sebesar 0,3 $\mathrm{cm}$.
Hasil analisis sidik ragam Fhitung lebih besar dari F-tabel. Hal ini menunjukkan bahwa pemberian Trichoderma sp pada berbagai konsentrasi perlakuan berpengaruh sangat nyata terhadap jumlah daun tanaman kedelai.Hasil uji BNT dapat dilihat pada Tabel 2

Tabel 2. Hasil Uji BNT Pengaruh Pemberian Jamur Trichoderma sp Terhadap Rata-rata Jumlah Daun Tanaman Kedelai pada Berbagai Konsentrasi Perlakuan.

\begin{tabular}{cc}
\hline Perlakuan & $\begin{array}{c}\text { Rata-rata Jumlah Daun Tanaman } \\
\text { Kedelai (Helai) }\end{array}$ \\
\hline $\mathrm{P}_{0}$ & $7 \mathrm{a}$ \\
$\mathrm{P}_{1}$ & $7,8 \mathrm{~b}$ \\
$\mathrm{P}_{2}$ & $8 \mathrm{~b}$ \\
$\mathrm{P}_{3}$ & $8,8 \mathrm{c}$ \\
$\mathrm{P}_{4}$ & $9 \mathrm{c}$ \\
$\mathrm{P}_{5}$ & $9 \mathrm{c}$ \\
\hline BNT $^{(\mathbf{0 , 0 5})} \mathbf{0 , 4}$ &
\end{tabular}

Keterangan: Rata-rata dalam tabel yang diikuti oleh huruf yang sama artinya tidak berbeda $\begin{array}{llll}\text { nyata } & \text { pada } & \text { uji } & \text { BNT }\end{array}$

Pada Tabel 2 dapat dilihat bahwa pemberian jamur Trichoderma sp terhadap jumlah daun tanaman kedelai yang tertinggi terdapat pada perlakuan $\mathrm{P}_{4}$ dan $\mathrm{P}_{5}$ dengan jumlah daun yang sama yaitu sebanyak 9 helai, sedangkan hasil terendah terdapat pada perlakuan $\mathrm{P}_{0}$ dengan jumlah daun sebanyak 7 helai.

Berdasarkan hasil analisis sidik ragam pemberian jamur Trichoderma sp terhadap tinggi tanaman kedelai didapatkan nilai $F_{\text {hitung }}$ lebih kecil dari $\mathrm{F}_{\text {tabel }}$ pada taraf 5\%, hal ini berarti bahwa pemberian jamur Trichoderma sp pada berbagai konsentrasi perlakuan berpengaruh tidak nyata terhadap tinggi tanaman kedelai, tetapi hasil analisis sidik ragam berpengaruh nyata terhadap diameter batang dan jumlah daun.

Pada Tabel 2, hasil analisis sidik ragam menunjukkan bahwa pemberian jamur Trichoderma sp pada berbagai konsentrasi perlakuan berpengaruh tidak nyata terhadap pertumbuhan tinggi tanaman kedelai, tetapi secara statistik terjadi kenaikan tinggi tanaman seiring dengan bertambahnya konsentrasi perlakuan jamur Trichoderma sp yang diberikan.Pemberian jamur Trichoderma sp pada berbagai konsentrasi perlakuanberpengaruh tidak nyata karena kemungkinan konsentrasi yang diberikan masih rendah sehingga belum menunjukkan pengaruh yang signifikan dalam menstimulasi pertumbuhan tinggi tanaman kedelai. Adanya perbedaan tinggi tanaman disebabkan karena adanya perbedaan konsentrasi Trichoderma $\mathrm{sp}$ yang diberikan.Menurut hasil penelitian Hersanti dkk (2000), introduksi jamur Trichoderma sp 20 gram $/ 2 \mathrm{~kg}$ tanah mampu meningkatkan tinggi tanaman, berat basah dan menekan perkembangan penyakit layu Fusarium pada tanaman cabai. Djafaruddin (2000), menambahkan bahwa biakan jamur Trichoderma $\mathrm{sp}$ yang diberikan ke areal pertanaman dapat berlaku sebagai biodekomposer yang 
mendekomposisi limbah organik menjadi kompos bermutu serta dapat berlaku sebagai biofungisida yang berperan untuk mengendalikan organisme patogen penyebab penyakit.

Pada Tabel 2, hasil uji BNT taraf $5 \%$ rata-rata pertumbuhan diameter batang tanaman kedelai menunjukkan bahwa $\mathrm{P}_{5}$ berbeda nyata dengan $\mathrm{P}_{0}, \mathrm{P}_{1}, \mathrm{P}_{2}$, $\mathrm{P}_{3}, \mathrm{P}_{4}$. Perlakuan $\mathrm{P}_{1}$ berbeda tidak nyata dengan $\mathrm{P}_{0} \quad$ (kontrol), sedangkan $\mathrm{P}_{2}$ berbeda tidak nyata dengan $\mathrm{P}_{3}$ dan $\mathrm{P}_{4}$.Pemberian jamur Trichoderma sp pada berbagai konsentrasi perlakuan berpengaruh sangat nyata diduga karena pemberian jamur Trichoderma sp dapat membantu merangsang pertumbuhan diameter batang tanamankedelai sehingga tanaman dapat tumbuh dengan baik. Penelitian Wahyu dan Pasetriyani (2006), menunjukkan bahwa introduksi 50 gram jamur Trichoderma sp/polibag dapat mempertahankan pertumbuhan (tinggi tanaman dan jumlah daun) serta hasil (jumlah dan bobot buah) pada tanaman tomat.

Pada Tabel 2, hasil uji BNT taraf $5 \%$ rata-rata pertumbuhan jumlah daun tanaman kedelai menunjukkan bahwaperlakuan $\mathrm{P}_{0}$ berbeda nyata dengan $\mathrm{P}_{1}, \mathrm{P}_{2}, \mathrm{P}_{3}, \mathrm{P}_{4}$ dan $\mathrm{P}_{5} . \mathrm{P}_{1}$ berbedatidak nyata dengan $\mathrm{P}_{2}$, sedangkan $\mathrm{P}_{3}$ berbeda tidak nyata dengan $\mathrm{P}_{4}$ dan $\mathrm{P}_{5}$.Pemberian jamur Trichoderma sp pada berbagai konsentrasi perlakuan berpengaruh sangat nyata diduga karena jamur Trichoderma $\mathrm{sp}$ dapat berasosiasi dengan akardanmenginfeksi akar tanaman sehingga akan terbentuk cabang akar yang lebih banyak, dengan bantuan cabang akar tersebut makaprosespenyerapan unsur hara menjadi lebih lancar. Dengan kebutuhan hara yang cukup maka prosesfisiologi pada tanaman akan berlangsungdengan baik. Hasil penelitian Suwahyono (2003), menunjukkan bahwa pemberian jamur Trichoderma sp akan membantu tanaman cepat berbuah serta meningkat jumlah daun dan diameter batang pada tanaman pisang, sedangkanpada tanaman selada pemberian jamur Trichoderma sp dapat meningkatkan jumlah akar dan daun menjadi lebih lebar.

Pemberian jamur Trichoderma sp akan mampu membantu pertumbuhan tanaman kedelai menjadilebih baik. Hal ini juga didukung dengan keberadaan jamur Trichoderma sp yang berasosiasi dengan tanaman dan membentuk mikorizha. Menurut Mulyani (2006), mikorhiza adalah gabungan dari hifa jamur yang bersimbiosis dengan akar muda tumbuhan yang keduanya saling mendapatkan keuntungan dari hidup bersama tersebut. Hubungan antara jamur Trichoderma sp dengan akar tanaman kedelaimerupakan simbiosis mutualisme, dimana tanaman diuntungkan dalam hal pertumbuhan maupun pengendalian penyakit sedangkan Trichoderma sp diuntungkan karena dapat menyerap nutrisi yang dihasilkan oleh tanaman.Jamur Trichoderma sp yang diaplikasikan kedalam tanah akan berasosiasi dengan akar tanaman dan menyelimuti akar yang kemudian masuk kedalam perakaran tanaman melalui rambut akar dan menginfeksi akar dengan cara masuk kedalam korteks dan menyebabkan selnya berpoliferasi sehingga jumlah sel didalam bintil akar meningkat. Akar yang terinfeksi Trichoderma sp akan membentuk akarakar cabang yang lebih banyak dibandingkan dengan akar yang tidak terinfeksi. Perakaran yang banyak tersebut dapat membantu penyerapan unsur hara menjadi lebih baik, sehingga tanaman dapat tumbuh dengan baik. Hasil penyerapan unsur hara akan diedarkan ke seluruh organ tanaman yang akan digunakan untuk proses fisiologi maupun pertumbuhan tanaman.

Berdasarkan hasil penelitian yang telah dilakukan diketahui bahwa semakin tinggi dosis Trichoderma sp yang diberikan pada tanaman kedelai maka 
semakin besar diameter batang tanaman dan semakin banyak jumlah daun pada tanaman kedelai. Berdasarkan hasil yang diperoleh menunjukkan bahwa perlakuan yang berbeda-bedadapat memberikan hasil yang beragam pada pertumbuhan tanaman kedelai. Menurut Wahyu dan Pasetriyani (2006), Trichoderma sp memilki peran yang sangat besar dalam menjaga kesuburan tanah dan memiliki potensi sebagai "kompos aktif" yang dapat dimanfaatkan untuk meningkatkan dan merangsang pertumbuhan akar, batang, daun, bunga dan memberikan hasil yang lebih baik pada tanaman tomat.

Trichoderma sp yang digunakan dalam penelitian ini adalah Trichoderma sp yang dibiakan pada media pelet. Menurut Niken (2009), Trichoderma sp digolongkan kedalam class Deuteromycetes. Perkembangan aseksualnya yaitu dengan menghasilkan konidiospora. Trichoderma $\mathrm{sp}$ bersel banyak berderet membentuk benang halus yang disebut hifa. Hifa pada jamur ini berbentuk pipih, bersekat dan bercabang-cabang membentuk anyaman yang disebut miselium. Miseliumnya dapat tumbuh dengan cepat dan dapat memproduksi berjuta-juta spora, karena sifatnya inilah Trichoderma sp dikatakan memiliki daya kompetitif yang tinggi. Dalam pertumbuhannya, bagian permukaan Trichoderma sp akan terlihat putih bersih dan kusam setelah dewasa, miselium memiliki warna hijau kekuningan.

Tanaman kedelai berkecambah sampai muncul ke permukaan tanah membutuhkan waktu 4-5 hari setelah tanam. Masa vegetatif tanaman kedelai berkisar antara 20 - 30 hari. Masa vegetative tanaman dimulai dari proses perkecambahan biji.Perkecambahan adalah munculnya plantula (tanaman kecil) dari dalam biji yang merupakan hasil pertumbuhan dan perkembangan embrio.Perkecambahan biji dimulai dengan proses penyerapan air (ambibisi). Pada saat proses ambibisi, kandungan air meningkat sehingga biji mengalami pengembangan dan pelunakan biji kemudian jaringan mulai aktif kembali dan mengalami pemecahan senyawa atau enzim menjadi bermolekul lebih kecil dan sederhana. Enzim disintesis untuk mencerna dan menggunakan berbagai cadangan makanan yang tersimpan didalam endosperm.Hasil pencernaan diangkut ke titik tumbuh yang akan digunakan untuk pertumbuhan. Struktur yang pertama kali muncul adalah radikula (calon akar) kemudian terjadi proses pembentukanorgan yang lainnya seperti plumula (calon batang) dan daunyang semuanya akan digunakan untukmelangsungkan hidupnya. Akar akan menyerapair, hara dan mineral didalam tanah. Batangberperan untuk memberi kekuatan danmenyokong tubuh tanaman, sementara daunberperan untuk pembentukan makanan melaluiproses fotosintesis. Hasil fotosintesis akandiedarkan keseluruh organ tanaman dan sisanya disimpansebagai cadangan makanan.Kebutuhan tanaman pada fase produksi akanterpenuhi dengan mudah apabila pertumbuhan vegetatif tanaman maksimal.

Pertumbuhan pada tanaman dikotil dapat dibedakan menjadi pertumbuhan primer dan pertumbuhan sekunder. Pertumbuhan primer yaitu pertumbuhan yang berasal dari aktivitas titik tumbuh yang menyebabkan perpanjangan batang dan penebalan daun, hal ini terjadi karena adanya aktivitas pembelahan sel parenkim dan pembentukan cabang dan daun. Sedangkan pertumbuhan sekunder yaitu pertumbuhan yang berasal dari aktivitas kambium yang menyebabkan pelebaran batang (Rukman, 2002).

\section{KESIMPULAN}

Dari hasil penelitian dapat disimpulkan bahwa pemberian jamur 
Trichoderma sp berpengaruh tidak nyata terhadap pertumbuhan tinggi tanaman kedelai, namunberpengaruh sangat nyata terhadap diameter batang dan jumlah daun pada tanaman kedelai. Hasil yang tertinggi pada Perlakuan Trichoderma sp yang diberikan dengan dosis 125 gram pelet Trichoderma sp/2kg tanah Perlakuan P5) dengan tinggi tanaman 41 $\mathrm{cm}$, diameter batang $0,5 \mathrm{~cm}$ dan jumlah daun 9 helai, sedangkan hasil terendah terdapat pada perlakuan $\mathrm{P}_{0}$ (kontrol/tanpa pemberian pelet Trichoderma $\mathrm{sp})$.

\section{DAFTAR PUSTAKA}

Balai Proteksi Tanaman Perkebunan Palembang. 2014. Jamur Trichoderma sp dalam Media Pelet. BPTP Palembang.

Djafaruddin.2000. Dasar-dasar Pengendalian Penyakit Tanaman. PT Bumi Aksara. Jakarta.

Herlina, L. 2009. Potensi Trichoderma harzianum sebagai Biofungisida pada Tanaman Tomat. Jurnal Biosainfitika. Vol. I, No. 1, Hal. $62-69$, Maret 2009.

Ismail, N dan T, Andi. 2011. Potensi Agens Hayati Trichoderma sp Sebagai Pengendali Hayati. BPTP Sulawesi Utara.

Kusumaningrum, L., R. Hastuti dan S. Haryanti. 2007. Pengaruh Perasan Sargassum crassifolium dengan Konsentrasi yang Berbeda Terhadap Pertumbuhan Tanaman Kedelai (Glycine max (L) Merril). Jurnal Buletin Anatomi dan Fisiologi. Vol. XV, No. 2, Oktober 2007.
Marianah, L. 2013. Analisis Pemberian Trichoderma sp Terhadap Pertumbuhan Kedelai. Balai Pelatihan Pertanian Jambi.

Mulyani, S. 2006. Anatomi Tumbuhan. Kanisius. Yogyakarta.

Niken. 2009. Mengenal Lebih Jelas Trichoderma sp. (Http//ayya.multiply.com). Diakses 13 April 2015.

Pebriyanti, D. 2013. Pengaruh Pemberian Jamur Antagonis Trichoderma sp pada Berbagai Konsentrasi Terhadap Perkecambahan Tomat (Solanum lycopersicum Mill) pada Tanah yang Mengandung Jamur Pythium sp. Skripsi. Universitas PGRI Palembang.

Rukman, R. 2002. Budidaya Kacangkacangan. Kansinus. Yogyakarta.

Suwahyono. 2003. Trichodermaspuntuk Pengendalian Hayati. Fakultas Biologi UGM. Yogyakarta.

Wahyu, Y dan E, Pasetriyani. 2006. Pengaruh Introduksi Jamur Trichoderma sp Terhadap Perkembangan Penyakit Layu (Fusarium oxysforum), Pertumbu han dan Hasil Tanaman Tomat. BPTP Jawa Barat.

Zamriyetti dan S, Rambe. 2002. Pertumbuhan dan Produksi Tanaman Kedelai (Glycine Max L. Merril) pada Berbagai Konsentrasi Pupuk Daun Grow More dan Waktu Pemangkasan. Fakultas Pertanian UNPAB. Medan. 